This is the final peer-reviewed accepted manuscript of:

Isotopic Labeling Studies Reveal the Patulin Detoxification Pathway by the Biocontrol Yeast Rhodotorula kratochvilovae LS11.

Pinedo C, Wright SAI, Collado IG, Goss RJM, Castoria R, Hrelia P, Maffei F, DuránPatrón R.

J Nat Prod. 2018 Dec 28;81(12):2692-2699

The final published version is available online at: DOI: $10.1021 / a c s . j n a t p r o d .8 b 00539$

Rights / License:

The terms and conditions for the reuse of this version of the manuscript are specified in the publishing policy. For all terms of use and more information see the publisher's website. 


\section{Isotopic labeling studies reveal the patulin detoxification pathway by the biocontrol yeast Rhodotorula kratochvilovae LS11}

Cristina Pinedo, ${ }^{\dagger}$ Sandra A. I. Wright, ${ }^{\ddagger}$ Isidro G. Collado, ${ }^{\dagger}$ Rebecca J. M. Goss ${ }^{\S}$ Raffaello Castoria, ${ }^{\perp}$ Patrizia Hrelia, ${ }^{J}$ Francesca Maffei, ${ }^{\circ}$ Rosa Durán-Patrón, ${ }^{\dagger *}$

†Departamento de Química Orgánica, Facultad de Ciencias, Campus Universitario Río San Pedro s/n, Torre sur, $4^{a}$ planta, Universidad de Cádiz, 11510, Puerto Real, Cádiz, Spain.

${ }^{\ddagger}$ Section of Biology, Faculties of Health and Occupational Studies \& Engineering and Sustainable Development, University of Gävle, 80176 Gävle, Sweden.

${ }^{\S}$ School of Chemistry, Biomedical Sciences Research Complex, University of St Andrews, Fife, Scotland, KY169ST, United Kingdom.

${ }^{\perp}$ Dipartimento Agricoltura, Ambiente, Alimenti, Università degli Studi del Molise, Via F. De Sanctis snc, 86100 Campobasso, Italy.

J Dipartimento di Farmacia e Biotecnologie, Alma Mater Studiorum-Università di Bologna, Via Irnerio, 48, 40126 Bologna, Italy

${ }^{\circ}$ Dipartimento di Scienze per la Qualità della vita, Alma Mater Studiorum-Università di Bologna, Campus Rimini, Corso D’Augusto 237, 47921 Rimini, Italy.

*Corresponding authors:

E-mail: rosa.duran@uca.es (R. Durán-Patrón). Tel: +34 956012718.

E-mail: francesca.maffei@ unibo.it (F. Maffei). Tel: +39 0541 434656. Fax: +39 0541 4343600). 


\begin{abstract}
Patulin (1) is a mycotoxin contaminant in fruit and vegetables products worldwide. Biocontrol agents, such as the yeast Rhodotorula kratochvilovae strain LS11 can reduce patulin (1) contamination in food. R. kratochvilovae LS11 converts patulin (1) into desoxypatulinic acid (DPA) (5), which is less cytotoxic than the mycotoxin (1) to in vitro human lymphocytes. In the present study, we report our investigations into the pathway of degradation of patulin (1) to DPA (5) by $R$. kratochvilovae. Isotopic labeling experiments revealed that 5 derives from patulin (1) through the hydrolysis of the $\gamma$ lactone ring and subsequent enzymatic modifications. The ability of patulin (1) and DPA (5) to cause genetic damage was also investigated by Cytokinesis-Block Micronucleus cytome assay on in vitro human lymphocytes. Patulin (1) was demonstrated to cause much higher chromosomal damage than DPA (5).
\end{abstract}


Patulin (1) is a well-known mycotoxin, biosynthesized by species belonging to the genera Penicillium, Aspergillus, Byssochlamys (anamorph Paecilomyces), Gymnoascus, Paecilomyces, and Scopulariopsis. ${ }^{1,2}$ It commonly occurs in fruits and in some other foods, which have been attached by these fungi. Patulin's (1) most noteworthy producer is $P$. expansum Link. (Trichocomaceae family), which causes blue mold of apples during postharvest storage. ${ }^{3}$

Patulin (1) is toxic to humans, animals, as well as to bacteria, yeasts and plants. ${ }^{3-18}$ In mammals, exposure to $\mathbf{1}$ can induce genotoxicity, embryotoxicity, immunotoxicity and neurotoxicity. ${ }^{3,7-18}$ Thus, human exposure to low levels of $\mathbf{1}$ is considered a major concern for public health. The Joint FAO/WHO Expert Committee on Food Additives has recommended a maximum tolerable daily intake of $0.4 \mu \mathrm{g} / \mathrm{kg}$ body weight/day. ${ }^{19} \mathrm{In}$ 2006 the European Commission set a maximum permitted level of $50 \mu \mathrm{g} / \mathrm{L}$ for fruit juice and of $10 \mu \mathrm{g} / \mathrm{kg}$ in products for children. ${ }^{20}$

Several post-harvest control strategies have been implemented to prevent, reduce or eliminate patulin (1) contamination of foodstuffs, including the use of chemical and physical methods. ${ }^{3,21-24}$ In recent years, biocontrol agents has emerged as a promising method to prevent infection of stored fruits by $P$. expansum and, as a consequence, eliminate patulin (1) contamination in fruits derivatives. ${ }^{25,26}$

Various microbial species, including biocontrol agents, exhibited the ability to degrade patulin (1). Saccharomyces cerevisiae degraded 1 to (E)- and (Z)-ascladiol (2, 3) during alcoholic fermentation of apple juice for cider production. ${ }^{27}$ More recently, it was reported that the bacteria Gluconobacter oxydans ${ }^{28}$ and Lactobacillus plantarum, ${ }^{29}$ the marine yeast Kodameae ohmeri ${ }^{30}$ and the terrestrial yeasts Candida guillermondi ${ }^{31}$ and Pichia caribbica ${ }^{32}$ also transformed 1 into $\mathbf{2}$ and 3. An additional metabolite, hydroascladiol (4), was formed in cell-free supernatant of a culture of L. plantarum supplemented with $\mathbf{1}^{29}(Z)$-Ascladiol (3) has been reported to be the product of nonenzymatic isomerization of $(E)$-ascladiol (2) catalyzed by sulfhydryl compounds, such as homocysteine, cysteine, and glutathione or dithiothreitol. ${ }^{33}$

In previous studies, we observed that the biocontrol yeast Rhodotorula kratochvilovae LS11 (basionym Rhodosporidium kratochvilovae, Sporidiobolaceae family) metabolized $\mathbf{1}$ generating a new degradation product, desoxypatulinic acid (DPA, 5) ${ }^{34}$ Studies carried out with another basidiomycete yeast allowed us to demonstrate that Sporobolomyces sp. IAM 13481 was also able to convert $\mathbf{1}$ to $\mathbf{5}$, in 
addition to $\mathbf{2}$ and $\mathbf{3}^{35}$ In a further report, a phytogenetically related yeast species, Rhodosporidium paludigenum (syn. Rhodotorula paludigena) was demonstrated to produce a biodegradation product of $\mathbf{1}$, which was putatively identified as DPA (5). ${ }^{36}$

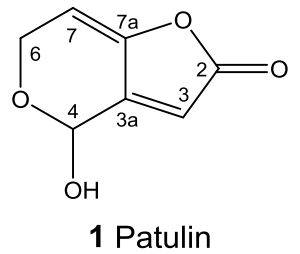

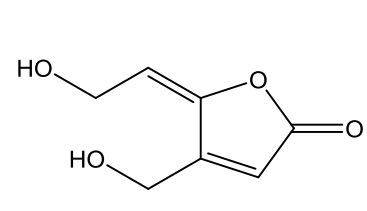

$2(E)$-Ascladiol

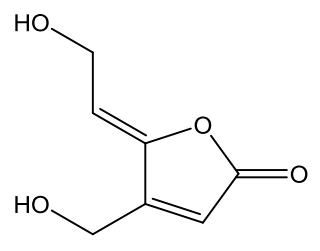

3 (Z)-Ascladiol

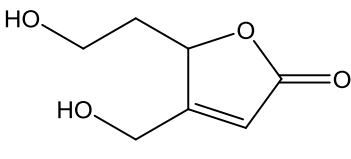

4 Hydroascladiol

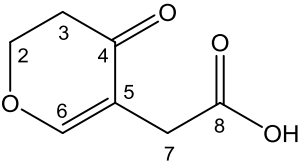

5 DPA

Cytotoxicities of patulin degradation products have been investigated. $(E)$ - and $(Z)$ ascladiol $(\mathbf{2}, \mathbf{3})$, unlike $\mathbf{1}$, were devoid of cytotoxic effects on human cell lines of liver, kidney, intestine and immune system. ${ }^{37}$ In addition, $\mathbf{2}$ did not produce cytotoxicity in an ex vivo porcine intestinal model tissue. ${ }^{38}$ On the other hand, DPA (5) was also much less cytotoxic than 1 to in vitro human lymphocytes ${ }^{34}$ and hepatic cell line. ${ }^{36}$ These conversions by microbial species can therefore be considered detoxification processes of the mycotoxin (1).

Previous isotopic labeling experiments with ${ }^{13} \mathrm{C}$ labeled patulin (1) have allowed us to demonstrate that DPA (5) is derived from the metabolism of $\mathbf{1}$ by $R$. kratochvilovae strain LS11. ${ }^{34}$ However, the biodegradation mechanism by which this conversion occurs is still unknown. In order to elucidate this detoxification pathway we followed herein the fate of several isotopic labels during the biodegradation process of $\mathbf{1}$ into $\mathbf{5}$ by the strain LS11. For this purpose, we prepared two ${ }^{13} \mathrm{C}$ labeled analogues of $\mathbf{1}$ through administering sodium $\left[1-{ }^{13} \mathrm{C}\right]$ - and $\left[1,2-{ }^{13} \mathrm{C}_{2}\right]$-acetates, separately, to resting cell cultures of $P$. expansum FS-7. We incubated the strain LS11 with these isotopically labeled analogues of $\mathbf{1}$ or with unlabeled $\mathbf{1}$, in the presence of either $\mathrm{H}_{2} \mathrm{O},{ }^{2} \mathrm{H}_{2} \mathrm{O}$, or $\mathrm{H}_{2}{ }^{18} \mathrm{O}$ to follow the degradation of the mycotoxin (1) by the yeast into DPA (5). Furthermore, to gain a better understanding of the toxicity of both patulin (1) and DPA (5), we evaluated and compared the chromosomal damage and the cytotoxic effects induced by the two compounds in cultured human lymphocytes by using Cytokinesis-Block Micronucleus cytome (CBMN cyt) assay. ${ }^{39}$ 


\section{RESULTS AND DISCUSSION}

Patulin (1) was labeled with ${ }^{13} \mathrm{C}$ by pulse feeding sodium $\left[1-{ }^{13} \mathrm{C}\right]$-and $\left[1,2-{ }^{13} \mathrm{C}_{2}\right]-$ acetates, separately, to two series of resting cell cultures of $P$. expansum FS-7. A timecourse study was carried out to determine the optimal time for feeding the isotopically labeled acetate to enable maximum production of highly labeled metabolite. As a result of this time-course study for the production of patulin (1), four day old resting cell cultures of $P$. expansum were fed with the above mentioned ${ }^{13} \mathrm{C}$ labeled sodium acetates. Extraction and purification of the fermentation broths led to the isolation of two ${ }^{13} \mathrm{C}$ labeled analogues of patulin (1), which were analyzed by means of ${ }^{13} \mathrm{C}$ NMR spectroscopy.

When $P$. expansum was fed with sodium $\left[1-{ }^{13} \mathrm{C}\right]$-acetate, significant enrichments with ${ }^{13} \mathrm{C}$ were observed at $\mathrm{C}-2, \mathrm{C}-3 \mathrm{a}$ and $\mathrm{C}-7$ of patulin (1), whilst the feeding experiment with sodium $\left[1,2-{ }^{13} \mathrm{C}_{2}\right]$-acetate led to enhanced signals for C-2, C-3 and C-6, and enhanced and spin-spin coupled signals between C-3a and C-4 and between C-7 and C-7a (Figure 1, Table 1), indicating that these positions resulted from the intact incorporation of two acetates. These findings are in agreement with the ${ }^{13} \mathrm{C}$ incorporation detected in patulin (1) by HREIMS after administration of sodium [1${ }^{13} \mathrm{C}$-acetate to $P$. expansum that we previously reported, where up to three ${ }^{13} \mathrm{C}$ labels were incorporated in $0.3 \%$ of the molecules. ${ }^{34}$

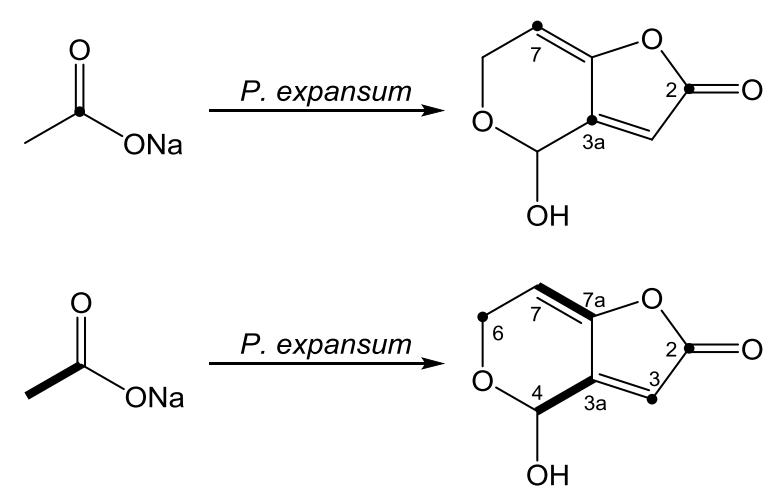

Figure 1. Labeling pattern resulting in patulin (1) after feeding Penicillium expansum FS-7 with sodium $\left[1-{ }^{13} \mathrm{C}\right]$ - and $\left[1,2-{ }^{13} \mathrm{C}_{2}\right]$-acetates. 
Table 1. Isotopic enrichment of carbons and coupling constants in patulin (1) after feeding Penicillium expansum FS-7 with sodium $\left[1-{ }^{13} \mathrm{C}\right]$ - or $\left[1,2-{ }^{13} \mathrm{C}_{2}\right]$-acetates.

\begin{tabular}{|c|c|c|c|}
\hline \multirow{2}{*}{$\begin{array}{c}\text { Carbon } \\
\text { atom }(N)\end{array}$} & \multirow{2}{*}{$\begin{array}{c}\delta_{\mathrm{C}} \\
\left(\mathrm{CD}_{3} \mathrm{OD}\right)\end{array}$} & \multirow{2}{*}{$\frac{\text { Atom } \%{ }^{13} \mathrm{C} \text { excess }{ }^{[\mathrm{a}]}}{\left[1-{ }^{13} \mathrm{C}\right] \text {-acetate }}$} & \multirow{2}{*}{$\frac{\boldsymbol{J}(\mathbf{H z})}{\left[1,2-{ }^{13} \mathrm{C}_{2}\right] \text {-acetate }}$} \\
\hline & & & \\
\hline 2 & 170.8 & 3.23 & enriched \\
\hline 3 & 111.0 & -0.22 & enriched \\
\hline $3 a$ & 153.5 & 3.36 & 56.8 \\
\hline 4 & 89.9 & 0.22 & 56.8 \\
\hline 6 & 60.3 & 0.00 & enriched \\
\hline 7 & 109.6 & 3.36 & 84.9 \\
\hline $7 \mathrm{a}$ & 147.9 & -0.07 & 84.9 \\
\hline \multicolumn{4}{|c|}{$\begin{array}{l}{ }^{\text {aa] }} \text { Atom } \%{ }^{13} \mathrm{C} \text { excess }=\left\{\left(\mathrm{R}_{N} / \mathrm{R}_{N(\mathrm{UL})} \times 1.1\right\}-1.1 \text {, where } \mathrm{R}_{N} \text { is the ratio of }\right. \\
\text { the peak intensity at } N \text {-position in labeled compound calculated on the } \\
\text { basis of the peak intensity at the C-6-position. Similarly, } \mathrm{R}_{N(\mathrm{UL})} \text { is the ratio } \\
\text { of the peak intensity at } N \text {-position in unlabeled compound. Value } 1.1 \text { is the } \\
\left.\text { theoretical }{ }^{13} \mathrm{C} \text { natural abundance (atom } \%\right) \text {. }\end{array}$} \\
\hline
\end{tabular}

The ${ }^{13} \mathrm{C}$ labeled analogues of patulin (1) obtained in the above mentioned experiments were subsequently administered to $R$. kratochvilovae LS11 cultures in order to follow the fate of the isotopic label during the metabolism of the compounds into DPA (5). The resulting labeled DPAs (5) were extracted after 3 days at acidic $\mathrm{pH}$, purified, and analyzed by ${ }^{13} \mathrm{C}$ NMR spectroscopy. Feeding experiment with the ${ }^{13} \mathrm{C}$ labeled analogue of patulin (1) from sodium $\left[1-{ }^{13} \mathrm{C}\right]$-acetate led to DPA (5) with enhanced signals at carbons C-3, C-5, and C-8. When strain LS11 was fed with labeled patulin (1) deriving from sodium $\left[1,2-{ }^{13} \mathrm{C}_{2}\right]$-acetate, the ${ }^{13} \mathrm{C}$ NMR spectrum of DPA (5) showed the incorporation of two intact $\mathrm{C}_{2}$ units for the carbon pairs C-3/C-4 and C-5/C6. In addition, ${ }^{13} \mathrm{C}$ enrichments at positions C-2, C-7 and C-8 were observed (Figure 2, Table 2). This pattern of observed couplings and enrichments suggests that DPA (5) derives from the metabolization of patulin (1) by the yeast through the biodegradation pathway shown in Scheme 1. 


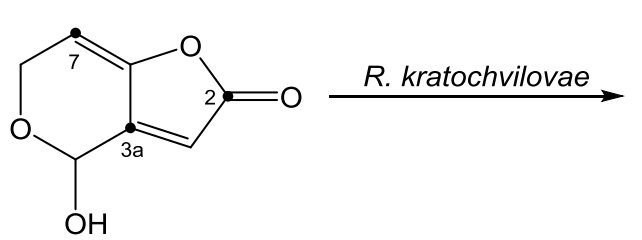<smiles>O=C(O)CC1=COCCC1=O</smiles><smiles>[R]C1CCCC1CC(=O)O</smiles><smiles>O=C(O)CC1=COCCC1=O</smiles>

Figure 2. Labeling pattern resulting in DPA (5) after feeding Rhodotorula kratochvilovae LS11 with molecules of patulin (1) deriving from cultures of Penicillium expansum FS-7 fed with sodium $\left[1-{ }^{13} \mathrm{C}\right]$ - or $\left[1,2-{ }^{13} \mathrm{C}_{2}\right]$-acetate.

Table 2. Isotopic enrichment of carbons and coupling constants in DPA (5) after feeding Rhodotorula kratochvilovae LS11 with molecules of patulin (1) deriving from cultures of Penicillium expansum FS-7 fed with sodium $\left[1-{ }^{13} \mathrm{C}\right]$ - or $\left[1,2-{ }^{13} \mathrm{C}_{2}\right]$-acetate.

\begin{tabular}{cccc} 
Carbon & $\boldsymbol{\delta}_{\mathbf{C}}$ & Atom $\%{ }^{\mathbf{1 3}} \mathbf{C}$ excess ${ }^{[\mathbf{a}]}$ & $\boldsymbol{J}(\mathbf{H z})$ \\
\cline { 3 - 4 } atom $(\boldsymbol{N})$ & $\left(\mathbf{C D}_{\mathbf{3}} \mathbf{O D}\right)$ & {$\left[1-{ }^{13} \mathrm{C}\right]$-acetate } & {$\left[1,2-{ }^{13} \mathrm{C}_{2}\right]$-acetate } \\
\hline 2 & 69.5 & 0 & enriched \\
3 & 36.9 & 1.51 & 40.0 \\
4 & 193.8 & -0.61 & 40.0 \\
5 & 114.4 & 5.12 & 71.4 \\
6 & 164.4 & -0.68 & 71.4 \\
7 & 32.1 & -0.49 & enriched \\
8 & 176.2 & 4.46 & enriched
\end{tabular}

[a] Atom $\%{ }^{13} \mathrm{C}$ excess $=\left\{\left(\mathrm{R}_{N} / \mathrm{R}_{N(\mathrm{UL})} \times 1.1\right\}-1.1\right.$, where $\mathrm{R}_{N}$ is the ratio of the peak intensity at $N$-position in labeled compound calculated on the basis of the peak intensity at the C-2-position. Similarly, $\mathrm{R}_{N(\mathrm{UL})}$ is the ratio of the peak intensity at $N$-position in unlabeled compound. Value 1.1 is the theoretical ${ }^{13} \mathrm{C}$ natural abundance (atom \%).

In order to explore the hydrolysis of the patulin (1) lactone ring, an experiment was conducted in which the ${ }^{13} \mathrm{C}$ labeled mycotoxin (1) from sodium $\left[1-{ }^{13} \mathrm{C}\right]$-acetate was biodegraded by $R$. kratochvilovae LS11 in a culture medium containing $25 \%(\mathrm{v} / \mathrm{v})$ of $\mathrm{H}_{2}{ }^{18} \mathrm{O} .{ }^{18} \mathrm{O}$ does not possess a magnetic moment and therefore is not detectable by NMR. However, it can be indirectly detected by ${ }^{13} \mathrm{C}$ NMR spectroscopy through the isotope-induced shift in the carbon atom directly attached to ${ }^{18} \mathrm{O} .{ }^{40}$ The low levels of 
incorporation of isotopically labeled water achievable in biosynthetic studies, can be difficult to observe. To enhance this, it is standard practice to carry out the labeling study on material that is ${ }^{13} \mathrm{C}$ enriched in the position to be oxygenated in order to make the indirect detection of ${ }^{18} \mathrm{O}$ more sensitive. In this experiment, labeling of DPA (5) was achieved by simultaneously incorporating ${ }^{13} \mathrm{C}$ from labeled patulin (1) derived from [1${ }^{13} \mathrm{C}$ ]-acetate feeding, and ${ }^{18} \mathrm{O}$ from $\mathrm{H}_{2}{ }^{18} \mathrm{O}$ present in the culture medium. The ${ }^{13} \mathrm{C}$ NMR spectum of the resultant DPA (5) showed an isotopically shifted resonance $0.024 \mathrm{ppm}$ for $\mathrm{C}-8$, which is in the expected order of magnitude for ${ }^{13} \mathrm{C}$ attached by simple bond to ${ }^{18} \mathrm{O}$ (Figure 3). ${ }^{41}$ This result clearly confirms the hydrolysis of the patulin (1) lactone ring by the water within the medium, leading to enol $\mathbf{6}$ outlined in Scheme 1, which is then rapidly isomerized into the more stable keto form 7 .

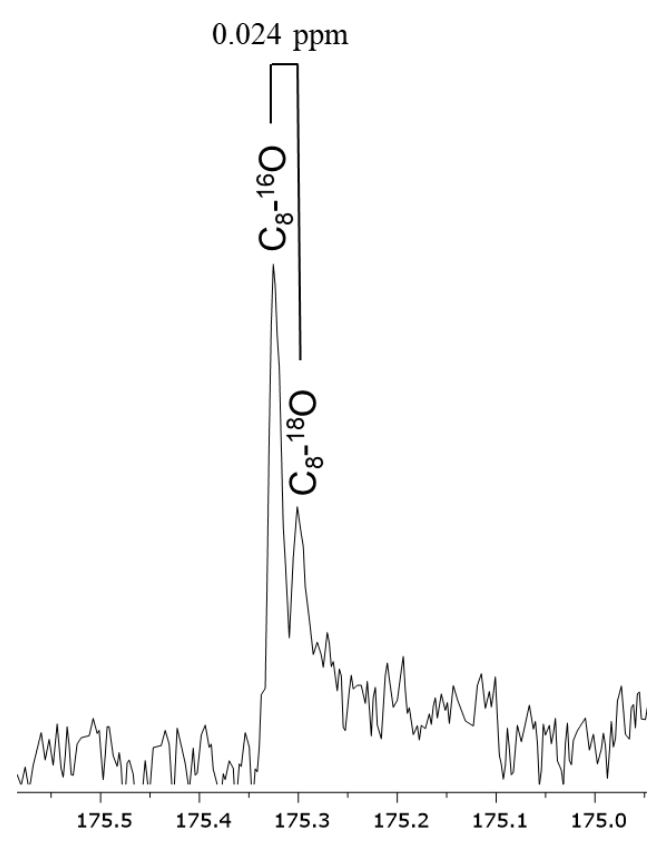

Figure 3. Region of the ${ }^{13} \mathrm{C}$ NMR spectrum of DPA (5) showing the ${ }^{18} \mathrm{O}$ isotopeinduced shift in the signal for C-8 after incubation of Rhodotorula kratochvilovae LS11 in a culture medium containing $\mathrm{H}_{2}{ }^{18} \mathrm{O}(25 \% \mathrm{v} / \mathrm{v})$ and ${ }^{13} \mathrm{C}$ labeled patulin (1), deriving from sodium $\left[1-{ }^{13} \mathrm{C}\right]$-acetate.

The hydrolysis of patulin (1) could be catalyzed under slightly acidic or basic conditions. In order to investigate the role of LS11 in the hydrolysis of patulin (1), the $\mathrm{pH}$ of the yeast culture medium was measured at the beginning $(\mathrm{pH} 4.5)$ and at the end ( $\mathrm{pH}$ 7.4) of the biodegradation experiment. Since at the beginning of the biodegradation process culture medium had an acidic $\mathrm{pH}$, patulin (1) was dissolved in water at $\mathrm{pH} 2$ 
and stirred for one week at room temperature. After this time period, there was no evidence of any transformation product as detected by TLC analysis. In addition, patulin (1) was dissolved in water at $\mathrm{pH} 8$ and also stirred for one week at room temperature, without degradation products being observed by TLC. These results, which are in agreement with those previously published on the stability of patulin (1) at acidic $\mathrm{pH},{ }^{42,43}$ suggests that the hydroxyl group bound to C-8 in DPA (5) derives from medium water by the action of a hitherto unidentified hydrolase (Scheme 1).

The subsequent experimental step was aimed at confirming the reduction and subsequent dehydration of the hydrolysis product (7) of patulin (1) to yield DPA (5). For this purpose, an experiment of patulin (1) biodegradation by $R$. kratochvilovae LS11 was carried out in a culture medium containing $25 \%(\mathrm{v} / \mathrm{v})$ of ${ }^{2} \mathrm{H}_{2} \mathrm{O}$. The ${ }^{2} \mathrm{H}$ NMR spectrum of the resultant DPA (5) showed only one signal at $\delta 3.00 \mathrm{ppm}$, corresponding to $\mathrm{D}-7$, as a consequence of the reduction of the double bond C-5/C-7 by the conjugate addition of a hydride to the $\alpha, \beta$-unsaturated acid 7 and subsequent dehydration of the resultant intermediate $\mathbf{8}$, as shown in Scheme 1. Recent studies have shown that $\mathbf{1}$ produces a marked increase, compared to the control, of the short-chain dehydrogenasereductase protein, as well as the level of expression of the corresponding gene in $R$. mucilaginosa. ${ }^{44}$ This finding reinforces the reduction step proposed in the detoxification pathway of patulin (1).

Taken together, all these results are consistent with the patulin (1) biodegradation pathway proposed in Scheme 1, according to which the $\alpha, \beta, \gamma, \delta$-unsaturated $\gamma$-lactone ring of the mycotoxin $\mathbf{1}$ is hydrolyzed by the action of a hitherto unidentified hydrolase to afford the intermediate $\mathbf{6}$, which is rapidly isomerized to 7 , probably without the need for any enzyme. Subsequent enzymatic reduction of the double bond C-5/C-7, through Michael-type reaction, and dehydration of the resultant intermediate 7 by the action of an unidentified dehydratase lead to DPA (5). 
Scheme 1. Degradation pathway of patulin (1) to DPA (5) by Rhodotorula kratochvilovae LS11. Labeling pattern resulting from experiments of LS11 incubation with $\mathrm{H}_{2}{ }^{18} \mathrm{O},{ }^{2} \mathrm{H}_{2} \mathrm{O}$ and ${ }^{13} \mathrm{C}$ labeled patulin (1) deriving from sodium [1$\left.{ }^{13} \mathrm{C}\right]$-acetate.

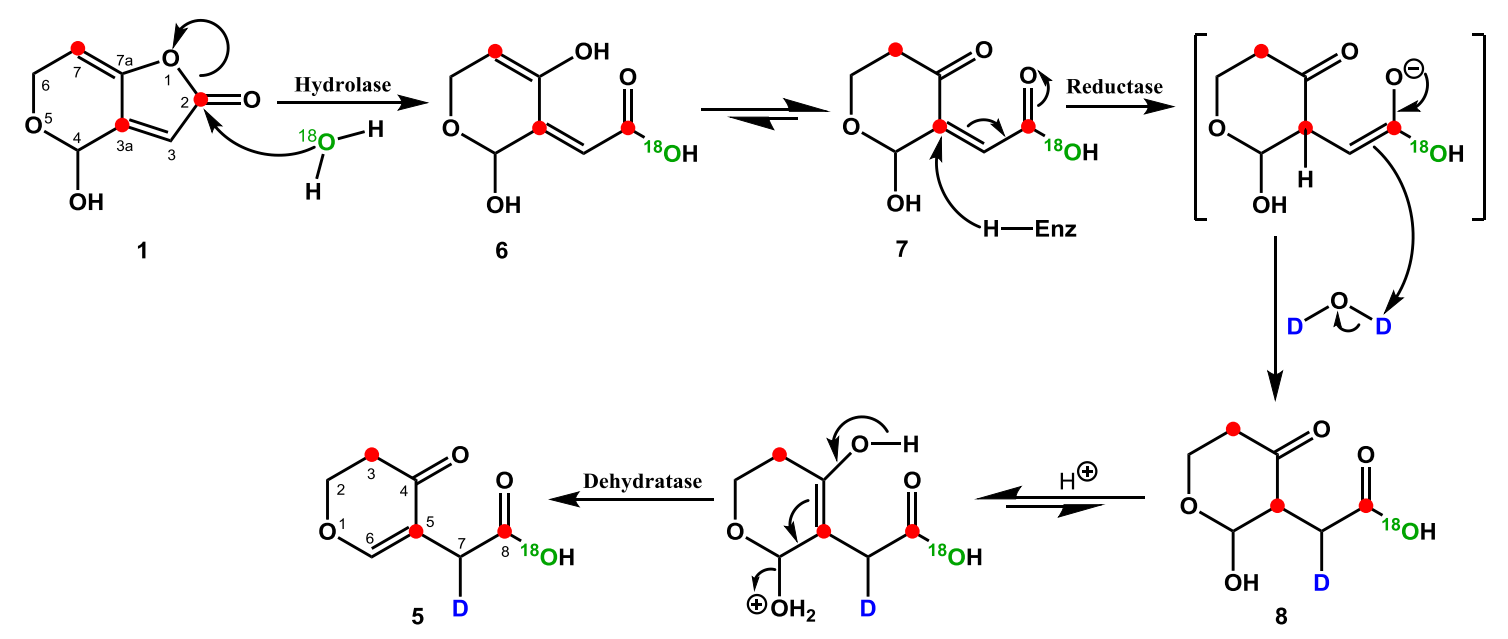

Previously, we have reported that DPA (5) was much less cytotoxic than patulin (1) to in vitro human lymphocytes, probably as a consequence of the loss of the hemiacetal group and the hydrolysis of the lactone ring. ${ }^{34}$ Patulin (1), unlike DPA (5), reacts with the thiol group present in the antioxidant tripeptide glutathione (GSH) and in enzymes, thus blocking their biological activity. ${ }^{34,45}$ Since patulin (1) is toxic to yeasts, they need to detoxify it. It has been observed that in Saccharomyces cerevisiae 12786 and Sporobolomyces sp. IAM 13481, the patulin (1) biodegradation process occurred in two steps, where the first involved an inhibition of growth and conditioning of cells to the toxic environment, and the second involved resumed microbial growth and successive biotransformation of patulin (1). ${ }^{46,47}$ As observed with the above mentioned yeast, $R$. kratochvilovae needs to detoxify patulin (1). Therefore, it can be stated that the pathway depicted in Scheme 1 shows the process of detoxification of patulin (1) to DPA (5) by R. kratochvilovae.

In order to have a better understanding of the toxic effects of patulin (1) and DPA (5), the CBMN cyt assay was performed on in vitro human lymphocytes. This assay is a comprehensive system for measuring DNA damage, cytostasis and cytotoxicity. DNA damage events were scored specifically in once-divided binucleated (BN) cells and include (a) MNi, a biomarker of chromosome breakage and/or whole chromosome loss, (b) NPBs, a biomarker of DNA misrepair and/or telomere end-fusions, and (c) nuclear 
buds (NBUDs), a biomarker of the elimination of amplified DNA and/or DNA repair complexes. Cytostatic effects were measured via the proportion of mono-, bi-, tri and tetranucleated cells, and cytotoxicity via necrotic and/or apoptotic cell ratios. ${ }^{39}$

Patulin (1) and DPA (5) were obtained as described in the Experimental section and dissolved in sterile double-distilled water for treatment of human lymphocyte cultures. Colcemid (COL) and ethyl-methanesulphonate (EMS) served as the standard positive controls. All lymphocyte cultures were treated for 24 hours with these compounds.

As shown in Table 3, patulin (1) at the highest concentration tested $(10 \mu \mathrm{M})$ induced a high percentage of necrotic cells (more than 20\%) while at the dose of $5 \mu \mathrm{M}$ significantly decreased the nuclear division index (NDI) (-35\%) with respect to the solvent control (sterile double-distilled water). These cytotoxic effects prevented a sufficient recovery of $\mathrm{BN}$ cells sufficient to allow chromosomal damage analysis. Patulin (1) also induced a significant increase of MNi frequency; the maximum increase observed at $1 \mu \mathrm{M}$ was about three-fold higher than the corresponding control value. The increase of MNi was concentration dependent. No significant increase in the frequency of NPBs with respect to the solvent control was recorded in the range of $0.10-1 \mu \mathrm{M}$ concentrations of patulin (1), whereas the frequencies of BUDs were significantly higher at doses of 0.5 and $1.0 \mu \mathrm{M}$. These results were consistent with previous observations made in both human and mammalian cells, ${ }^{9-12}$ and confirm the ability of patulin (1) to cause chromosomal damage and to interfere with DNA. As expected, we recorded a significant increase in $\mathrm{MNi}$ frequency with respect to the solvent control in the treatment with COL. Moreover, the treatment with EMS induced a significant increase in the frequencies of all three DNA damage events as compared to those observed in the solvent control.

Interestingly, DPA (5) did not induce any cytotoxic effect in the concentration range of $0.1-10 \mu \mathrm{M}$, thus analysis of the three DNA damage events could be performed in the lymphocyte cultures. The treatment with DPA (5) exhibited significant differences as compared to the treatment with patulin (1) for MNi and BUDs. No elevated level of either MNi and BUDs was observed in lymphocytes treated with 0.5-1.0 $\mu \mathrm{M}$ of 5, and the frequencies recorded were significantly lower than those induced by patulin (1) in the same concentration range. Only the highest concentrations of $5(5$ and $10 \mu \mathrm{M})$ induced significant differences as compared to the solvent control for MNi and BUDs. On the other hand, treatment with DPA (5) at any concentration did not increase the frequency of NPBs. 
Table 3. Mean ( \pm SD) frequencies of MNi, NPBs and BUDs in BN cells and NDI in human lymphocytes treated in vitro with patulin (1) or DPA (5).

\begin{tabular}{|c|c|c|c|c|c|}
\hline \multicolumn{2}{|c|}{ Treatment $(\boldsymbol{\mu M})$} & $\begin{array}{c}\text { MNi/1000 BN } \\
\text { cells }\end{array}$ & $\begin{array}{c}\text { NPBs/1000 BN } \\
\text { cells }\end{array}$ & $\begin{array}{c}\text { BUDs/1000 BN } \\
\text { cells }\end{array}$ & NDI \\
\hline Patulin (1) & $\begin{array}{l}0.10 \\
0.50 \\
1.00 \\
5.00 \\
10.00\end{array}$ & $\begin{array}{l}5.33 \pm 1.00 \\
12.33 \pm 2.08^{\mathrm{a}, \mathrm{b}} \\
14.67 \pm 2.08^{\mathrm{a}, \mathrm{b}} \\
\text { toxic } \\
\text { toxic }\end{array}$ & $\begin{array}{l}1.33 \pm 0.58 \\
1.33 \pm 0.58 \\
1.67 \pm 0.58 \\
\text { toxic } \\
\text { toxic }\end{array}$ & $\begin{array}{l}1.00 \pm 1.00 \\
4.67 \pm 1.53^{\mathrm{a}} \\
6.67 \pm 2.08^{\mathrm{a}, \mathrm{b}} \\
\text { toxic } \\
\text { toxic }\end{array}$ & $\begin{array}{l}1.73 \pm 0.03 \\
1.67 \pm 0.04 \\
1.61 \pm 0.03 \\
\text { toxic } \\
\text { toxic }\end{array}$ \\
\hline DPA (5) & $\begin{array}{l}0.10 \\
0.50 \\
1.00 \\
5.00 \\
10.00\end{array}$ & $\begin{array}{l}5.00 \pm 1.00 \\
6.33 \pm 1.53 \\
7.33 \pm 1.15 \\
9.00 \pm 1.00^{\mathrm{a}} \\
9.67 \pm 1.15^{\mathrm{a}}\end{array}$ & $\begin{array}{l}1.00 \pm 1.00 \\
1.00 \pm 1.00 \\
1.00 \pm 1.00 \\
1.33 \pm 0.58 \\
1.67 \pm 0.58\end{array}$ & $\begin{array}{l}1.33 \pm 0.58 \\
2.00 \pm 1.00 \\
2.33 \pm 1.15 \\
4.67 \pm 1.52^{\mathrm{a}} \\
6.33 \pm 1.52^{\mathrm{a}}\end{array}$ & $\begin{array}{l}1.75 \pm 0.03 \\
1.69 \pm 0.03 \\
1.64 \pm 0.03 \\
1.60 \pm 0.03 \\
1.56 \pm 0.04\end{array}$ \\
\hline $\begin{array}{l}\text { Solvent con } \\
\text { (double dis } \\
\text { water) }\end{array}$ & & $5.33 \pm 1.55$ & $1.33 \pm 0.58$ & $1.33 \pm 0.58$ & $1.77 \pm 0.08$ \\
\hline EMS (240 & & $13.33 \pm 1.53^{\mathrm{a}}$ & $8.67 \pm 1.52$ & $7.33 \pm 2.52$ & $1.64 \pm 0.04$ \\
\hline $\operatorname{COL}(0.02$ & & $20.33 \pm 2.08^{\mathrm{a}}$ & $1.67 \pm 0.58$ & $2.33 \pm 1.15$ & $1.67 \pm 0.03$ \\
\hline
\end{tabular}

The $\alpha, \beta$-unsaturated carbonyl group is commonly recognized as an alert for mutagenicity due to its reactivity with cellular nucleophilic amines and thiols. ${ }^{48}$ Patulin (1), a $\alpha, \beta, \gamma, \delta$-unsaturated $\gamma$-lactone, could display its cytotoxic and chromosomedamaging effects by forming covalent adducts with these types of compounds, since small lactones are known to act as alkylating agents. ${ }^{49}$ It has been suggested that $\mathbf{1}$ can interact irreversibility with nucleophilic groups of DNA leading to chromosomal damage and cell cycle disturbance. ${ }^{14}$ Recently, Pfenning et al. ${ }^{50}$ reported that patulin (1) reacts with nucleophilic centers of DNA bases, both in the absence and in the presence of GSH, to yield several mono- and di-substituted DNA base adducts as well as mixed patulin-GSH-nucleobase adducts. The initial step for obtaining these di-adducts is a Michael-like addition of the thiol group of GSH or the amine group of the DNA bases to $\delta$ position of unsaturated lactone moiety of patulin (1) to yield a reactive enol-lactone, which can add nucleophiles of DNA bases to the carbonyl carbon of the mycotoxin (1). Formation of patulin-nucleobase di-adducts could contribute to the increase on MNi and BUD observed in cells treated with patulin (1). On the other hand, formation of patulinGSH and patulin-GSH-nucleobase di- or tri-adducts could cause indirect DNA damage by depletion of the intracellular pool of GSH and antioxidant enzymes (superoxide dismutase and catalase), ${ }^{51}$ subsequent increase of $\operatorname{ROS}^{16,52}$ and of lipid peroxidation products. $^{53}$ 
At a molecular level, DPA (5) is a carboxylic acid whose structure contains an $\alpha, \beta$ unsaturated ketone, so we could expect the addition of nucleophiles to C-6 of 5 through a Michael-type addition reaction. However, we shown that DPA (5) does not react with $\mathrm{GSH}^{34}$ In addition, it has also been reported that the adducts resulting from the reactions of patulin (1) with 4-bromothiophenol, $\mathrm{N}$-acetylcysteine, or GSH, whose structures are similar to $\mathbf{5}$, did not undergo further addition of sulfur containing nucleophiles. $^{45,54}$ The lack of reactivity of DPA (5) could be due to the mesomeric effect $+\mathrm{M}$ produced by ring oxygen on the C-6 of $\mathbf{5}$, which renders this carbon, in contrast to C-7 of patulin (1), insufficiently electrophilic for Michael-type additions by nucleobases or cellular thiols. The electrophilic structure of DPA (5) could therefore explain the lower genotoxicity of this patulin (1) degradation and detoxification product.

In conclusion, we have prepared two ${ }^{13} \mathrm{C}$ labeled analogues of patulin (1) through administering sodium $\left[1-{ }^{13} \mathrm{C}\right]-$ and $\left[1,2-{ }^{13} \mathrm{C}_{2}\right]$-acetates, separately, to cultures of $P$. expansum. Feeding experiments with the ${ }^{13} \mathrm{C}$ labeled analogues of patulin (1), ${ }^{2} \mathrm{H}_{2} \mathrm{O}$ and $\mathrm{H}_{2}{ }^{18} \mathrm{O}$ enabled us to demonstrate that DPA (5) is a detoxification product that derives from the mycotoxin patulin (1) through the hydrolysis of the $\alpha, \beta, \gamma, \delta$-unsaturated $\gamma$ lactone ring and subsequent reduction of the double bond C-5/C-7 through a Michaeltype reaction, and dehydration of the resultanting intermediate 7. DPA (5) causes much less chromosomal damage than patulin (1) on human lymphocytes in vitro as shown by the CBMC cyt assay. The low cytotoxicity and genotoxicity of DPA (5) could be due to the lack of reactivity of this compound with cellular nucleophilic amines and thiols, possibly because of deactivation of its carbon C-6 by the ring oxygen.

The biodegradation pathway elucidated makes the foundation for identifying the microbial genes involved in the various enzymatic steps. As a result, new strategies for monitoring or reducing the levels of patulin (1) in food can be developed.

\section{EXPERIMENTAL SECTION}

General Experimental Procedures. ${ }^{1} \mathrm{H}$ and ${ }^{13} \mathrm{C}$ NMR spectra were recorded on Agilent 400 and $600 \mathrm{MHz}$ spectrometers using $\mathrm{CD}_{3} \mathrm{OH}$ as solvent (Merck, Darmstadt, Germany). TLC was performed on Merck Kiesegel $60 \mathrm{~F}_{254}, 0.25 \mathrm{~mm}$ thick. Silica gel $60 \mathrm{PF}_{254}$ (60-100 mesh, Merck) was used for column chromatography.

Reagents and Labeled Precursors. All reagents were purchased from SigmaAldrich (Milan, Italy). Sodium $\left[1-{ }^{13} \mathrm{C}\right]$-acetate (isotopic purity 99 atom $\%{ }^{13} \mathrm{C}$ ), sodium 
$\left[1,2-{ }^{13} \mathrm{C}_{2}\right]$-acetate $\left(99\right.$ atom $\left.\%{ }^{13} \mathrm{C}\right)$ and $\mathrm{H}_{2}{ }^{18} \mathrm{O}\left(97\right.$ atom $\left.\%{ }^{18} \mathrm{O}\right)$ were obtained from the Euriso-Top company (Saint Aubin, France). $\mathrm{D}_{2} \mathrm{O}$ (99.9 atom \% D) was obtained from Merck (Darmstadt, Germany). Both isotope-labeled sodium acetates were dissolved in water and sterilized through $0.22 \mu \mathrm{m}$ Millex GP (Millipore) filters before being added to the flasks containing the culture medium for microbial growth. $\mathrm{H}_{2}{ }^{18} \mathrm{O}$ and $\mathrm{D}_{2} \mathrm{O}$ were filter-sterilized prior to use.

Microorganisms. All microbial strains used in this study were obtained from the culture collection of the Dipartimento Agricoltura, Ambiente, Alimenti, Università del Molise, Italy. Conidial stock suspensions of Penicillium expansum FS-7 were maintained viable in $80 \%$ glycerol at $-40{ }^{\circ} \mathrm{C}$. Cells of the yeast Rhodotorula kratochvilovae LS11, originally isolated from an olive tree, were preserved on PDA medium (200 g of potatoes, $20 \mathrm{~g}$ of D-glucose, and $20 \mathrm{~g}$ of agar per liter of distilled water) at $4{ }^{\circ} \mathrm{C}$.

Preparation of Labeled Patulin. P. expansum strain FS-7 was cultivated at $25{ }^{\circ} \mathrm{C}$ and $150 \mathrm{rpm}$ in Erlenmeyer flasks $(500 \mathrm{ml})$ containing $300 \mathrm{~mL}$ of PDB medium $(200 \mathrm{~g}$ of potatoes and $20 \mathrm{~g}$ of D-glucose per liter of distilled water) diluted with $\mathrm{H}_{2} \mathrm{O}$ to a final ratio 1:10. Each flask was inoculated with fresh conidia to a final concentration of $4 \times$ $10^{6}$ conidia/ml. After 4 days of incubation, the mycelia were transferred into the same number of Erlenmeyer flasks (500 mL), each containing $300 \mathrm{~mL}$ of PDB medium diluted as above and a filter-sterilized aqueous solution of the labeled precursor. Three days after administration of the precursor, the culture medium and mycelia were separated by filtration. The broth was saturated with $\mathrm{NaCl}$ and extracted with ethyl acetate $(\times 3)$. The organic extract was washed with $\mathrm{H}_{2} \mathrm{O}(\times 3)$, dried over anhydrous $\mathrm{Na}_{2} \mathrm{SO}_{4}$, and the solvent evaporated under reduced pressure. ${ }^{34}$ The residue was purified by column chromatography on $\mathrm{Si}$ gel with an increasing gradient of ethyl acetate in $n$ hexane as eluent. Fractions containing patulin (1) were detected by TLC, collected and analyzed by ${ }^{1} \mathrm{H}$ NMR. The signals observed in the ${ }^{1} \mathrm{H}$ NMR spectrum were coincident with those shown by the commercial sample.

Labeled patuline (1) from sodium $\left[1-{ }^{13} \mathrm{C}\right]$-acetate. In accordance with the above procedure, 4 flasks inoculated with $P$. expansum FS-7 were fed with a filter-sterilized solution of sodium $\left[1-{ }^{13} \mathrm{C}\right]$-acetate in $\mathrm{H}_{2} \mathrm{O}$ to a final concentration of $300 \mathrm{ppm}$. Extraction of the broth yielded a crude extract (120.2 $\mathrm{mg}$ ), which was purified as 
described in the general method to afford $55.0 \mathrm{mg}$ of labeled patulin (1). The isotope incorporations are shown in Table 1.

Labeled patulin (1) from sodium $\left[1,2-{ }^{13} C_{2}\right]$-acetate. A filter-sterilized aqueous solution of sodium $\left[1,2-{ }^{13} \mathrm{C}_{2}\right]$-acetate was added to one flask inoculated with $P$. expansum to a final concentration of $233 \mathrm{ppm}$. Extraction of the broth yielded a crude extract (35.9 mg), which was purified as described above to yield $20.7 \mathrm{mg}$ of labeled patulin (1). The coupling constants are shown in Table 1.

Biodegradation of Patulin (1) by R. kratochvilovae LS11. A suspension of $R$. kratochvilovae LS11 cells $\left(1.0 \times 10^{5} \mathrm{CFU} / \mathrm{ml}\right)$ obtained from a 2-3 days-old culture on PDA was added to a $500 \mathrm{ml}$ Erlenmeyer flask containing $200 \mathrm{~mL}$ of Lilly-Barnett medium (10.0 $\mathrm{g}$ of D-glucose, $2.0 \mathrm{~g}$ of L-asparagine, $1.0 \mathrm{~g}$ of $\mathrm{KH}_{2} \mathrm{PO}_{4}, 0.5 \mathrm{~g}$ of $\mathrm{MgSO}_{4} \cdot 7 \mathrm{H}_{2} \mathrm{O}, 0.01 \mathrm{mg}$ of $\mathrm{FeSO}_{4} \cdot 7 \mathrm{H}_{2} \mathrm{O}, 8.7 \mathrm{mg}$ of $\mathrm{ZnSO}_{4} \cdot 7 \mathrm{H}_{2} \mathrm{O}, 3.0 \mathrm{mg}$ of $\mathrm{MnSO}_{4} \cdot 7 \mathrm{H}_{2} \mathrm{O}, 0.1 \mathrm{mg}$ of biotin, and $0.1 \mathrm{mg}$ of thiamine per liter of medium) supplemented with $150 \mathrm{ppm}$ of patulin (1). The yeast was incubated at $25{ }^{\circ} \mathrm{C}$ and 150 rpm. The biodegradation was monitored on a daily basis by TLC, using toluene/ethyl acetate/formic acid 5:4:1 (v/v/v) as the eluent system. After complete biodegradation of patulin (1), the culture medium and the yeast cells were separated by centrifugation for $20 \mathrm{~min}$ at $6000 \mathrm{rpm}$. The broth was acidified to $\mathrm{pH} 2$ with an aqueous solution of $\mathrm{HCl}$ $2 \mathrm{M}$, saturated with $\mathrm{NaCl}$, and extracted with ethyl acetate $(\times 3)$. The EtOAc extract was washed with $\mathrm{H}_{2} \mathrm{O}(\times 3)$, dried over anhydrous $\mathrm{Na}_{2} \mathrm{SO}_{4}$, and the solvent evaporated under reduced pressure. The residue was purified by chromatography on a Si gel column, using toluene/ethyl acetate/formic acid 5:4:1 (v/v/v) as the solvent system. Fractions containing DPA (5) were detected by TLC, collected and analyzed by ${ }^{1} \mathrm{H}$ NMR. The spectrum achieved was identical to that shown by a real sample.

Biodegradation of labeled patulin (1) deriving from sodium $\left[1-{ }^{13} \mathrm{C}\right]$-acetate. $R$. kratochvilovae LS11 was grown for 4 days in the presence of labeled patulin (1) coming from the feeding of $P$. expansum with sodium $\left[1-{ }^{13} \mathrm{C}\right]$-acetate in accordance with the above procedure. Extraction of the broth yielded a crude extract $(26.6 \mathrm{mg})$, which was purified as described above to afford $18.0 \mathrm{mg}$ of labeled DPA (5). The relative incorporations are shown in Table 2.

Biodegradation of labeled patulin (1) deriving from sodium $\left[1,2-{ }^{13} C_{2}\right]$-acetate. The yeast was grown for 3 days in the presence of labeled patulin (1) coming from the feeding of $P$. expansum with sodium $\left[1,2-{ }^{13} \mathrm{C}_{2}\right]$-acetate (see above). Extraction of the 
broth yielded a crude extract $(26.1 \mathrm{mg}$ ), which was purified as above to obtain $10.2 \mathrm{mg}$ of labeled DPA (5). The coupling constants are reported in Table 2.

Biodegradation of patulin (1) in $\mathrm{H}_{2}{ }^{18} \mathrm{O}$. A $50 \mathrm{~mL}$ Erlenmeyer flask, containing 20 $\mathrm{mL}$ of Lilly-Barnett medium in $25 \%$ of $\mathrm{H}_{2}{ }^{18} \mathrm{O}$ and supplemented with $150 \mathrm{ppm}$ of labeled patulin (1) obtained from the feeding of $P$. expansum with sodium $\left[1-{ }^{13} \mathrm{C}\right]$ acetate, was inoculated with a suspension of $R$. kratochvilovae LS11 cells $\left(1.0 \times 10^{5}\right.$ $\mathrm{CFU} / \mathrm{ml}$ ). The yeast was incubated as described above for 6 days. Extraction of the broth yielded a crude extract $(3.4 \mathrm{mg})$, which was purified as above to afford $1.2 \mathrm{mg}$ of labeled DPA (5).

Biodegradation of patulin (1) in ${ }^{2} \mathrm{H}_{2} \mathrm{O}$. A suspension of $R$. kratochvilovae LS11 cells $\left(1.0 \times 10^{5} \mathrm{CFU} / \mathrm{ml}\right)$ was added to an Erlenmeyer flask $(100 \mathrm{~mL})$ containing $40 \mathrm{~mL}$ of Lilly-Barnett medium in $25 \%$ of $\mathrm{D}_{2} \mathrm{O}$ supplemented with $150 \mathrm{ppm}$ of unlabeled patulin (1). The yeast was incubated as described above for 5 days. Extraction of the broth yielded a crude extract $(6.1 \mathrm{mg})$, which was purified as above to afford $3.2 \mathrm{mg}$ of labeled DPA (5).

Isolation of Unlabeled Patulin (1) and DPA (5). P. expansum strain FS-7 was cultivated at $25{ }^{\circ} \mathrm{C}$ and $150 \mathrm{rpm}$ in 6 Erlenmeyer flasks $(500 \mathrm{ml})$, each containing 300 $\mathrm{mL}$ of $\mathrm{PDB}$ medium diluted with $\mathrm{H}_{2} \mathrm{O}$ to a final ratio 1:10. Each flask was inoculated with fresh conidia to a final concentration of $4 \times 10^{6}$ conidia/mL. After 4 days of incubation, the culture medium and mycelia were separated by filtration. The broth was extracted and purified using the methodology described above for the isolation of labeled patulin (1), which provided $128.0 \mathrm{mg}$ of $\mathbf{1}$.

Four Erlenmeyer flasks (500 mL), each containing $200 \mathrm{~mL}$ of Lilly-Barnett medium supplemented with $150 \mathrm{ppm}$ of $\mathbf{1}$, were inoculated with a suspension of $R$. kratochvilovae LS11 (1.0 x 10 $\mathrm{CFU} / \mathrm{mL})$ cells from a 2-3 days old culture on PDA. The yeast was incubated for 4 days at $25^{\circ} \mathrm{C}$ and $150 \mathrm{rpm}$. At this time point, the culture medium and the yeast cells were separated by centrifugation. The medium was extracted and purified in accordance with the methodology described above for the isolation of labeled DPA (5), which yielded $34.0 \mathrm{mg}$ of $\mathbf{5}$.

Block Micronucleus Cytome Assay. The assay was set up using blood samples from 3 healthy, non-smoking adult males who were less than 40 years old, as provided by from AVIS (Italian Association of Voluntary Blood Donors). Lymphocytes were separated from whole blood using a density gradient (Histopaque 1077), washed twice 
in RPMI 1640 medium, and then cultured at a concentration of $2 \times 10^{6}$ cells in $5 \mathrm{~mL}$ of RPMI 1640 medium $\left(4 \times 10^{5} / \mathrm{mL}\right)$ supplemented with $15 \%$ fetal calf serum $(\mathrm{FCS})(\mathrm{v} / \mathrm{v})$, $0.5 \%$ phytohaemagglutinin $(\mathrm{v} / \mathrm{v}), 1 \%$ penicillin-streptomycin solution $(\mathrm{v} / \mathrm{v})$, and $1 \mathrm{mM}$ L-glutamine solution. The cultures were incubated at $37{ }^{\circ} \mathrm{C}$ in a humid atmosphere in the presence of $5 \% \mathrm{CO}_{2}{ }^{55}$

After $44 \mathrm{~h}$ of incubation, all cultures were supplemented with cytochalasin-B (Cyt B) at a final concentration of $6 \mu \mathrm{g} / \mathrm{mL}$. After $48 \mathrm{~h}$, lymphocytes cultures were treated with an aqueous solution of patulin (1) or DPA (5) in sterile double-distilled water to obtain final concentrations of $0.10,0.50,1,5$ and $10 \mu \mathrm{M}$. Sterile double-distilled water was used as the solvent control, whereas positive controls were EMS ( $240 \mu \mathrm{g} / \mathrm{mL})$, an alkylating agent, and COL $(0.02 \mu \mathrm{g} / \mathrm{mL})$, a microtubule-disrupting tubulin-binding agent.

At the end of the 72-h incubation period, the lymphocytes were collected and treated with a mild hypotonic treatment (RPMI 1640 medium: $\mathrm{H}_{2} \mathrm{O}$ 1:2, supplemented with $2 \%$ FCS) for $2 \mathrm{~min}$, and then fixed in ice-cold methanol: acetic acid (1:1). The slides were prepared by cytocentrifuge, air-dried, and stained with May Grunwald-Giemsa. ${ }^{56}$ All of them were coded prior to scoring. Scoring was done by using a Zeiss Axioplan light microscope at $\times 1000$ magnification under oil immersion. MNi, NPBs and BUDs were scored according to the criteria described by Fenech et $\mathrm{al}^{57}$ by examining at least 2000 BN cells for each concentration of the compounds under assessment (1000 for each culture). The frequencies of MNi, NPBs or BUDs in $1000 \mathrm{BN}$ cells were then calculated for each treatment. Cell-cycle parameters were evaluated by classifying 1000 cells according to the number of nuclei. The nuclear division index (NDI) was calculated according to the eq. 1, where M1 through M4 indicate the number of cells with 1-4 nuclei, and $\mathrm{N}$ indicates the total number of scored cells. ${ }^{56}$ Necrotic and apoptotic cells were scored according to the guidelines reported by Fenech et al. ${ }^{57}$ So, 1000 cells were counted and scored as either mononucleated, binucleated, trinucleated, tetranucleated, apoptotic or necrotic, and percentages of the different types of cells were calculated. Assays with high \% of necrotic or apoptotic or few BN cells were classified as 'toxic'.

$$
N D I=\frac{M 1+2 M 2+3 M 3+4 M 4}{N}
$$

The experiments were performed in triplicate and each concentration was tested in two parallel cultures. Data from the three experiments were pooled. 
Statistical Analysis. All values from toxicity experiments are means \pm S.D. Student's $t$-test was used for comparing the mean of a specific treatment with control mean. $\mathrm{P} \leq 0.05$ was considered as statistically significant.

\section{ASSOCIATED CONTENT}

\section{Supporting Information}

${ }^{1} \mathrm{H}$ and ${ }^{13} \mathrm{C}$ NMR spectra for patulin (1), and ${ }^{1} \mathrm{H},{ }^{13} \mathrm{C}$ and ${ }^{2} \mathrm{H}$ NMR spectra for DPA (5) (PDF).

\section{ACKNOWLEDGEMENTS}

This research was supported by grants from MINECO (AGL2015-65684-C2-1-R and HI2007-0026) and Italian Ministry of University and Research (Project PRIN $\mathrm{n}^{\circ}$ 2006072204). Use of NMR facilities at the Servicio Centralizado de Ciencia y Tecnología (SCCYT) of the University of Cádiz is acknowledged.

\section{REFERENCES}

(1) Benkerroum, N. Int. Dairy J. 2016, 62, 63-75.

(2) Pitt, J. J.; Hocking, A. D. Fungi and Food Spoilage. Blackie Academic \& Professional, London, 1997.

(3) Wright, S. A. I. Curr. Opin. Food Sci. 2015, 5, 105-109.

(4) Madhyastha, M. S.; Marquardta, R. R.; Masi, A.; Borsa, J.; Frohllch, A. A. J. Food Protect. 1994, 57, 48-53.

(5) Iwahashi, Y.; Hosoda, H.; Park, J. H.; Lee, J. H.; Suzuki, Y.; Kitagawa, E.; Murata, S. M.; Jwa, N.-S.; Gu, M.-B.; Iwahashi, H. J. Agr. Food Chem. 2006, 54, 19361942.

(6) Bottalico, A.; Lerario, P.; Visconti, A. Phytopathol. Mediterr. 1980, 19 (2-3), 196198.

(7) Puel, O.; Galtier, P.; Oswald, I. P. Toxins 2010, 2, 613-631.

(8) De Melo, F. T.; De Oliveira, I. M.; Greggio, S.; Dacosta, J. C.; Gueceva, T. N.; Saffi, J.; Henriques, J. A.; Rosa, R. M. Food Chem. Toxicol. 2012, 50, 3548-3555.

(9) Zhou, A. M.; Jiang, L. P.; Geng, C. Y.; Cao, J.; Zhoumg, L. F. Toxicon 2009, 53, 584-586.

(10) Ayed-Boussema, I.; Abassi, H.; Bouaziz, C.; Hlima, W. B.; Ayed, Y.; Bacha, H. Environ. Toxicol. 2013, 6, 299-306. 
(11) Alves, I.; Oliveira, N. G.; Laires, A.; Rodrigues, A. S.; Rueff, J. Mutagenesis 2000, 15, 229-234.

(12) Liu, B. H.; Yu, T. S.; Li, S. Y.; Su, M. C.; Wang, M. C.; Shih, S. M. Tocicol. Appl. Pharm. 2003, 191, 255-263.

(13) Donmez-Altuntas, H.; Gokalp-Yildiz, P.; Bitgen, N.; Hamurcu, Z. Mycotoxin Res. 2013, 29, 63-70.

(14) Glaser, N.; Stopper, H. Food Chem. Toxicol. 2012, 50, 1796-1801.

(15) Zhou, S. M.; Jiang, L. P.; Geng, C. Y.; Cao, J.; Zhong, L. F. Toxicon 2010, 55, 390-395.

(16) Ferrer, E.; Garcia, J.; Font, G.; Ruiz, M. J. Toxicol. In vitro 2009, 23, 1504-1509.

(17) Korte, A. Mutat. Res. 1980, 78, 41-49.

(18) Song, E.; Xia, X.; Su, C.; Dong, W.; Xian, Y.; Wang, W.; Song, Y. Food Chem. Toxicol. 2014, 7, 122-127.

(19) World Health Organization. Evaluation of certain food additives and contaminants. Forty-fourth report of the joint FAO/WHO expert committee on food additives. WHO Technical Report Series 859, pp 36-38, Geneva 1995.

(20) European-Commission. Regulation (EC) No 1881/2006 of 19 December 2006 setting maximum levels for certain contaminants in foodstuffs, L 364/5, 2006.

(21) Moake, M. M.; Padilla-Zakour, O. I.; Worobo, R. W. Compr. Rev. Food Sci. Food Saf. 2005, 1, 8-21.

(22) Kabak, B.; Dobson, A. D. W.; Var, I. Crit. Rev. Food Sci. 2006, 46, 593-619.

(23) Assatarakul, K.; Churey, J. J.; Manns, D. C.; Worobo, R. W. J. Food Protect. 2012, 75, 717-724.

(24) Sant'Ana, A. S.; Rosenthal, A.; Massaguer, P. R. Food Res. Int. 2008, 41, 441453.

(25) Halász, A.; Lásztity, R.; Abonyi, T.; Bata, Á. Food Rev. Int. 2009, 25, 284-298.

(26) Mahunu, G. K.; Zhang, H.; Yang, Q.; Li, C.; Zheng, X. Crit. Rev. Microbiol 2016, 42 (4), 643-655.

(27) Moss, M. O.; Long, M. T. Food Addit. Contam. 2002, 19 (4), 387-399.

(28) Ricelli, A.; Baruzzi, F.; Solfrizzo, M.; Morea, M.; Fanizzi, F. P. Appl. Environ. Microb. 2007, 73, 785-792.

(29) Hawar, S.; Vevers, W.; Karieb, S.; Ali, B. K.; Billington, R.; Be, J. Food Control 2013, 34, 502-508.

(30) Dong, X.; Jianga, W.; Lia, C.; Maa, N.; Xua, Y.; Menga, X. Food Addit. Contam. 
A. 2015, 32 (3), 352-360.

(31) Chen, Y.; Peng, H.-M.; Wang, X; Li, B.-Q; Long, M.-Y; Tian, S.-P. Toxins 2017, 9, 2-13.

(32) Zheng, X.; Li, Y.; Zhang, H.; Apaliya, M. T.; Zhang, X.; Zhao, L.; Jiang, Z.; Yang, Q.; Gu, X. Biol. Control 2018, 123, 127-136.

(33) Sekiguchi, J.; Shimamoto, T.; Yamada, Y.; Gaucher, G. M. Appl. Environ. Microl. 1983, 45, 1939-1942.

(34) Tannous, J.; Snini, S. P.; El Khoury, R.; Canlet, C.; Pinton, P.; Lippi, Y.; Alassane-Kpembi, I.; Gauthier, T.; El Khoury, A.; Atoui, A.; Zhou, T.; Lteif, R.; Oswald, I. P.; Puel, O. Arch Toxicol. 2017, 91, 2455-2467.

(35) Maidana, L.; Gerez, J. R.; El Khoury, R.; Pinho, F.; Puel, O.; Oswald, I. P.; Bracarense, A. P. F. R. L. Food Chem. Toxicol. 2016, 98, 189-194.

(36) Castoria, R.; Mannina, L.; Durán-Patrón, R.; Maffei, F.; Sobolev, A. P.: De Felice, D. V.; Pinedo-Rivilla, C.; Ritieni, A.; Ferracane, R.; Wright, S. A. I. J. Agric. Food Chem. 2011, 59, 11571-11578.

(37) Ianiri, G.; Idnurm, A.; Wright, S. A.; Durán-Patrón, R.; Mannina, L.; Ferracane, R.; Ritieni, A.; Castoria, R. Appl. Environ. Microb. 2013, 79, 3101-3115.

(38) Zhu, R.; Feussner, K.; Wua, T.; Yan, F.; Karlovsky, P.; Zheng, X. Food Chem. 2015, 179, 1-5.

(39) Fenech, M. Nat. Protoc. 2007, 2, 1084-1104.

(40) Vederas, J. C. Nat. Prod. Rep. 1987, 4, 277-337.

(41) Hansen, P. E. Annu. Rep. NMR Spectrosc. 1984, 15, 105-234.

(42) Lovett, J.; Peeler, J. T. J. Food Sci. 1973, 38, 1094-1095.

(43) Drusch, S.; Kopka, S.; Kaeding, J. Food Chem. 2007, 100, 192-197.

(44) Zheng, X.; Yang, Q.; Zhao, L.; Apaliya, M. T.; Zhang, X.; Zhang, H. Sci. Rep. 2017, 7, doi: 10.1038/s41598-017-14078-5.

(45) Fliege, R.; Metzler, M. Chem. Res. Toxicol. 2000, 13, 373-381.

(46) Sumbu, Z. L.; Thonart, P.; Bechet, J. Appl. Environ. Microbiol. 1983, 45, 110115.

(47) Ianiri, G.; Panfili, G.; Fratianni, A.; Pinedo, C.; Castoria, R. Toxins 2017, 9, 61.

(48) Ashby, J; Tennant, R. W.; Zeiger, E.; Stasiewicz, S. Mutat. Res. 1989, 223, 73103.

(49) Bräse, S.; Encinas, A.; Keck, J.; Nising, C. F. Chem. Rev. 2009, 109, 3903-3990. 
(50) Pfenning, C.; Esch, H. L.; Fliege, R.; Lehmann L. Arch. Toxicol. 2016, 90, 433448.

(51) Zhang, B.; Peng, X.; Li, G.; Xu, Y.; Xia, X.; Wang, Q. Toxicon 2015, 94, 1-7.

(52) Janzowski, C.; Glaab, V.; Mueller, C.; Straesser, U; Kamp, H. G.; Eisenbrand, G. Mutagenesis 2003, 18, 465-470.

(53) Guéraud, F.; Atalay, M.; Bresgen, N.; Cipak, A.; Eckl, P. M.; Huc, L.; Jouanin, I.; Siems, W.; Uchida, K. Free Radical. Res. 2010, 44, 1098-1124.

(54) Fliege, R., Metzler, M. Chem. Res. Toxicol. 2000, 13, 363-372.

(55) Maffei, F.; Carbone, F.; Cantelli Forti, G.; Buschini, A. M.; Poli, P.; Rossi, C.; Marabini, L.; Radice, S.; Chiesara, E.; Hrelia, P. Environ. Int. 2009, 35, 1053-1061.

(56) Eastmond, D. A.; Tucker, J. D. Environ. Mol. Mutagen. 1989, 13, 34-43.

(57) Fenech, M.; Crott, J.; Turner, J.; Brown, S. Mutagenesis 1999, 14, 605-612. 
Abstract Graphic

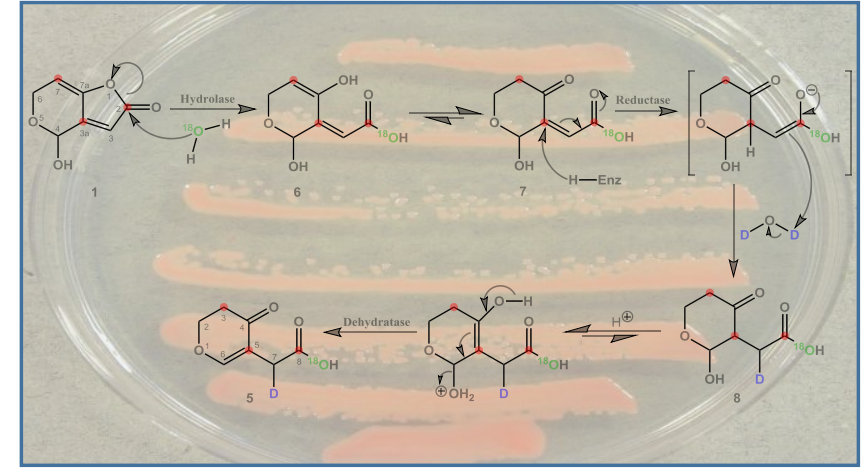

